\section{THE USES AND DATES OF ANCIENT} TEMPLES.

I PROPOSE in the present article to make some very general statements concerning the work so far done on the orientation of ancient temples, and to bring together some of the chief conclusions to which it has led.

I may begin by stating that the inquiry has becil carried on at intervals during the last nineteen years -that is, since March, I890-when I observed the magnetic bearing of the temple axis of the Parthenon. From 1891 to 1894 the research was almost entirely limited to Egypt. "The Dawn of Astronomy," published in 1894 , gives the result.

The first definite conclusion arrived at deals with the use of the temples; why they were built, and for what purpose. It was found that the Egyptians carefully built their temples so that the rising and the setting of certain stars, and of the sun at certain times of the year, could be watched along the temple axis by the priest in the sanctuary.

It was not until after my first winter in Egypt that I learned that Nissen, of Bonn, had anticipated me in suggesting that this might have been so, and that several references to the practice which $\mathbf{I}$ had made out occur in the inscriptions.

One of the chief difficulties in the Egyptian work arose from the fact that in most cases the date of the foundation of the temples was unknown. There were, however, some notable exceptions where the results of the orientation theory could be compared with records, and in these there was a perfect agreement, which also enlightened us on the method employed by the Egyptian astronomer-priests for reducing to a minimum the disadvantageous effects of the change of the places of stars brought about by the precessional movement. ${ }^{1}$

The next conclusion dealt with the actual astronomical observations made by the ancient Egyptians. They were of three classes:-(r) To determine the time at night. The stars used for this purpose I have called "clock-stars." (2) To observe a star rising or setting "heliacally"-that is, about an hour before sunrise on the chief festivals. (3) To determine when the sun had reached a certain part of its yearly path at which the festivals occurred.

For (I), as they had no instruments, they used a star rising near the north point of the horizon, and watched its movement round the pole; one quarter of its path would, of course, represent six hours, and so on. The stars so used were the brightest ones in the Great Bear and the Dragon. Stars rising near the south point of the horizon were also observed, and, doubtless, for the same purpose. For (2) any bright star rising or setting at the proper time between the north and south points would do; as a matter of fact, they used Capella, Spica, the Pleiades, Sirius, $\alpha$ Centauri, Canopus, and others. For (3) they commenced with a year beginning in May-the " May year," the first used in Britain, and still determining the quarter-days in Scotland; later they passed to the "solstitial" year, June $2 \mathrm{r}$, the beginning of the Nile rise and the longest day, being the new new at widely different epochs, dedication of the same temple to different stars Denderah was built either to orientation tbeory tells us that the temple Great Bear in 4950 B C. or the principal star of Draco in 3 roo B.C. or both; the inscriptions tell us that the temple was founded in the times of the Shemsu Heru before Mena, whose date, according to Budge's "History of Egypt," was 4400 B.C., and was afterwards restored by Pepi, whose date, according to the same authori1y, was 3233 B.C.

At Annu there was a restoration of an old temple by Usertsen (2433 B.C.). The story is told in a roll still extant. The theory tells us that, as at Denderah, this restoration was undertaken to watch the rise of the principal star of the Drasto in founded to watch the rise of the principal star of the Great Bear in 5200 B.C. NO. 2064, VOL. 80] year's day. This is the origin of our present English year.

The inquiry thus begun in Egypt was subsequently carried on in Greece by Mr. Penrose with admirable results, because there he was able to deal with temples the foundation dates of which are known within narrow limits.

The first attempt to apply the orientation theory to British monuments was made by Mr. Penrose and myself in Igor at Stonehenge.

At the first blush there appears to be no resemblance between the Egyptian and Greek temples and the British stone monuments, but a careful study of both shows that this view is an erroneous one.

The study of the British monuments from the astronomical point of view has enabled us to grasp one object which, in spite of their varied forms and complexities, they all had to fulfil. It also enables us to classify them, and this classification not only suggests the order of their evolution, but shows their strict relationship to the Egyptian temples. This was the next advance. The demonstration is as follows.

The simplest of our ancient British stone monuments is represented by what is called a stone-row or avenue; good examples of these are to be seen at Merrivale; one is a single line of stones; the other is a compound avenue consisting of two double lines of stones running parallel with each other at some distance apart. The most famous compound avenus in our own country is that of Challacombe, on Dartmoor, which consisted once of eight rows of stones. I am sorry to say only two or three rows now remain.

Avenues were in some cases built of earth instead of stones; one at Stonehenge can still be studied; it extends towards the north-east from the centre of the temple and naos.

The next form we have to consider after the avenue is the cromlech or dolmen - that is, the skeleton of an old barrow. Here again we get the gradual elaboration from a single cromlech to compound ones. A good example of the former is that at Trevethy, in Cornwall. In this, which consists of very large stones, the only entrance into the chamber is provided by a small portion cut out at the bottom corner of one of the stones. There is another very good example called the Devil's Den, near Avebury, which is rather more simple than the cromlech at Trevethy. It consists of one big stone supported by three others.

Another kind of monument called a cove must be regarded as an uncovered cromlech. It consists of three stones occupying three sides of a square, the open side indicating the direction; the finest example is at Avebury.

Cromlechs do not always occur singly. At times they are compounded into pairs or triplets, as at Plas Newydd.

We next find a combination of the avenue and cromlech. In this form the direction of the opening of the cromlech is defined by marking and extending it with a double line of stones. We thus get a creep or alley-way, or allee, as the French archæologists call it, and this may be either open or covered-allee ouverte or allée couverte; fougou is the Cornish term for the latter form.

The best example that I have seen of this combination of avenue and cromlech in Britain is that at Bryn Celli Ddu. This, like the avenue at Stonehenge, looks out to the north-east of the horizon; in fact, it is practically parallel to that avenue. The most perfect example of a barrow containing a cromlech with an alley-way is at Maeshowe, in the Orkneys. The cromlech is in the centre of a still existing mound; it is a very elaborate one, with side 
(sleeping) chambers and a small chamber at the end, and a long alley-way which points to a menhir not far away called the "Barn Stone," and to the place of sunset in December, twenty days from the winter solstice.

The most compound example of avenues and cromlechs that I know of as yet is one of which photographs and particulars have recently been sent to me by Captain Devoir, of the French Navy; in it we have three cromlechs and three alley-ways, using the same outlook, and, doubtless, once covered by one barrow.

One alley-way is directed to the sunrise in May, another to sunrise at the winter solstice, and there is another directed to a "clock-star" rising near the north point, so that, in association with one barrow, we have three distinct and well-marked alleys in directions with which we are perfectly familiar.

This oneness of aim which the orientation theory enables us to discover leads us further.

In the avenues, alley-ways, and cromlechs we are absolutely face to face with the ground-plan of Egyptian temples, so much so that there can be no question that those who built those magnificent monuments in Egypt some 2000 , 3000, or 4000 years B.c. got their ideas of the buildings they wished to erect from the traditions of people who built cromlechs and who had lived in and used them.

A general plan of Thebes shows how in Egyptian architecture, in a country of wonderful civilisation, large population, and infinite wealth, we get a tremendous elaboration of the avenue; each temple is provided with one, long or short, leading outwards from the pylon.

The avenue, which in our case is built of rough stone, is elaborated into long lines of beautifully carved sphinxes, and, further, if we study the most elaborate Egyptian temples, we see there are, in the temple itself, very many openings in one straight line in various walls; in some places we have an allee ouverte, and in others an allée couverte.

These all lead to a closed chamber at the end, a darkened chamber, the naos or the holy of holies, which is nothing but a glorified cromlech.

The temple access never pierces the end of the closed chamber any more than the wall was pierced at the back of the cromlech, but it led to a darkened chamber, so that here we have the closest possible relationship from the architectural point of view between the British cromlech and the most elaborate temples at Thebes, while from the astronomical point of view the similarity of use is obvious.

So much, then, for the intimate connection between the avenue and the cromlech, however simple or complicated either may be, and the strict relationship of both to the Egyptian temples.

But there is another and completely different set of ancient monuments still to be classified. I refer to circles, which, like the avenues and cromlechs, may be simple or compound. Archæologists so far have not noticed the close relationship of circles with avenues and cromlechs, for the reason that the circles to which their attention has been almost entirely confined only represent one part of the apparatus. When we consider a circle and its outstanding stone indicating a certain direction, the strongest astronomical resemblance to the alignments of avenues and cromlechs is at once apparent.

There is no doubt that the circle represents an encrmous advance in astronomical knowledge, possibly, to a certain extent, connected with the building conditions brought about by the poverty or the economical ideas of the people who constructed them. In densely populated and rich Egypt a temple was devoted to the rising or setting of one heavenly body, whether star or sun, the place of rising or setting being indicated by the long temple axis, and each sacred place contained many such temples, because there were many heavenly bodies to be watched. The temple of Amen-Ra, if contracted for now, could not, I fancy, be built for less than 5,00o,oool. sterling, and it might take ten or fifteen years to erect. But it simply had one outlook, one use.

Now, to carry on this method of observation and worship where the population was scarce, the best and cheapest thing to do would be to build a bank or set up a line of stones to represent a temple axis, or to build a circle to represent a sanctuary, and from its centre to imitate various temple axes by sightlines marked out by a stone or barrow at some distance outside the circle. Six such outstanding marks, each of stone set up in a day or two, would then replace, and quite effectually from the astronomical point of view, six majestic temples taking tens of years to build, and the elaborate system of avenues and cromlechs represented by all the temples at Thebes or in any other locality, however numerous.

Only the holy of holies as a dark chamber would have to go; the centre of the circle would replace it as the priest's place. That was a matter for the priests, and had nothing to do with astronomy. In any case, from the astronomical point of view, what was done by the Theban priests by building all these majestic temples could be done by one circle with properly arranged outstanding stones, so that the circle represents a distinct advance over the idea connected with the avenues and the cromlechs.

We shall not, then, be far wrong in supposing circle building to represent a later development, and this view is strengthened by the fact that there are no circles in Egypt, where the avenue-cromlech system is most developed.

The next upshot of the inquiries arrived at, soon after I had measured several stone monuments in Cornwall and on Dartmoor, was that the directions indicated by the avenues, cromlechs, and circles with outstanding stones were certainly not helter-skelter. When they were classified it was found that only a small number of directions was used-that is to say, directions embracing sunrise and sunset throughout the year, and directions to the north or south parts of the horizon which the sun never reaches.

Next it was found that these directions were practically the same, and had the same uses, as those 1 had previously studied in Egypt-in short, that the British avenues and stone circles bear precisely the relationship to the Egyptian temples indicated above. The "clock-stars" used in the British monuments were the precise equivalents of the stars in Ursa Major and Draco used by the ancient Egyptians, when we take the difference of latitude between Egypt and Britain $\left(25^{\circ}\right)$ and the effect of the precessional movement on the declination of the star into account. The same may be said of the "morning stars" they employed.

These "morning stars" were of very great importance. We are familiar with them from Bible references. These were stars which rose about an hour before the sun itself rose. In the earliest times there were sacrifices, and the morning sacrifice was a very elaborate affair, which required about an hour for its preparation, so that unless the priest could get some idea of the time of the actual sunrise some hour or so before the sun itself rose, he might go very wrong, and be either too early or too late at the moment of the rise of the great luminary. When the alignNO. 2064, VOL. 80] 
ments to the places of the sun at different periods of the year were investigated, another conclusion of first-rate importance was arrived at.

At first the all-important positions of the sun, as indicated by the alignments, were not the solstices or the equinoxes, but at intermediate points when the sun occupied the declinations $16^{\circ} 20^{\prime} \mathrm{N}$. and $\mathrm{S}$. The year was thus defined by the sun's stations in May, August, November, and February.

This I have called the "May year," a vegetation year. I think it must be acknowledged that one of the most important results of the new method of looking at monuments has been the demonstration of the existence in early times in Britain of a year which began in May or November and ended in November or May; and this, one of the teachings of the monuments touching our early history, will in the future greatly help folklorists and others interested in antiquity and the dawn of the so-called Celtic literature. There is now no doubt, after the researches of the Rev. J. Griffith, that the Welsh Gorsedd circle brings before us, in stone, traditions of a time when the May year was in vogue.

The reason that we had that year before we had the real astronomical year, which works from the solstices in June and December to the equinoxes in March and September, is that the worship and use of the sun began before the length of the year had been made out, and that the worship was at its highest in Babylonia and Egypt at the time the sun was giving to us the most that it could givethat is to say, the harvests of the fruits of the earth.

The earliest temple that I know of directed to the May sun is at Memphis, which must date from some 4000 years B.C., and it may well be that at that time little was known about the length of the year, because it looks very much as though the Theban cult was established at Thebes as opposed to Memphis some 2000 years after the date I have mentioned, simply because the Egyptian astronomers had then found out the length of the year and had begun to use it.

One reason why they reckoned their year from solstice to solstice, which is what we do now, was probably because at the solstice the sun rises at the same place on the horizon for three days, whereas the determination of the exact position of the sun on May 6 or March $2 \mathrm{I}$ is a matter of difficulty as compared with the determination of the solstice. When Mr. Penrose and myself were making observations, we were led to the belief that the present Stonehenge, with its complete sarsen stone circles, is relatively a modern affair, and that there had been at Stonehenge, long before the sarsen circles were erected, an old temple directed to the "May year." I have since found in many cases traces of the "May year" anticipating the solstitial year. The solstitial cult in Britain followed the "May year" cult, just in the same way as in Egypt the solstitial cult at Thebes followed the "May year" cult at Memphis and Heliopolis.

In relation to the sun's seasonal times, then, we find temple axes, avenues, and circles with outstanding stones indicating the direction in which sunrise or sunset was to be looked for at the critical times of the year-that is, the beginning of May, August, November, and February, dealing with the May year, and the longest and shortest days of the solstitial year.

In connection with these solar alignments, evidence is forthcoming that in some cases warning was given of the chief festivals by erecting stones marking the sun's sunrise place from some twenty. one days before they occurred. It is thus possible that the structure of the Roman calendar with the $2 \mathrm{I}$ dies ante calendas and the ecclesiastical period of Lent, which was originally of three weeks' duration, may have had their origin in the stone-circle practices.

The next main conclusion derived from the work has to do with the dates of erection of the various monuments. With regard to these, I limit myself now to Britain.

The determination of dates is rendered possible by the change of the declination of the sun at the solstices and of stars, brought about by astronomical causes into which we need not now enter. This declination, indeed, is constantly changing, but we have, thanks to the researches of Stockwell and Dr. Lockyer, tables of the declinations of the solstitial sun and of the principal stars, century by century, as far back as 4000 в.с. It is fortunate that, to determine the declination to which the direction of each monument corresponds, very simple observations alone are required. It is as well to recapitulate them here. First, the exact direction of the temple axis or avenue, or of the outstanding stones or barrows, as seen from the circle, in astronomical terminology their azimuth, is obtained by measurements made at the actual monument or on the 25 -inch Ordnance map. The angular height of the horizon on this line has next to be measured. With these data and the latitude, the declination (that is the distance from the equator) of the body observed along the sightline indicated can be calculated. The solar group of monuments practically does not help us with regard to dates, for the reason that the change in the position of the sun every succeeding Iooo years is very small, but the change in the position of the stars every Iooo years, or even 300 years in some cases, is considerable, so that in the matter of dates we are thrown back almost entirely upon the stars. Still, there is one solar temple so perfectly arranged at Stonehenge that it has been possible to suggest the date for it within something like 200 years; the measures of that, quite independently of any view determined from other considerations, gave us about $x 680$ B.c. for the erection of the solstitial sarsen stones at Stonehenge.

Observations have been made at a large number of monuments in Britain during the course of the last three or four years, by the help of a great many friends in different regions, who find it a very pleasant occupation for their holidays. Already something like I4O or I5O alignments of avenues or of cromlechs, or of outstanding stones, have been measured, and II3 results have already been tabulated. These are as follows :-

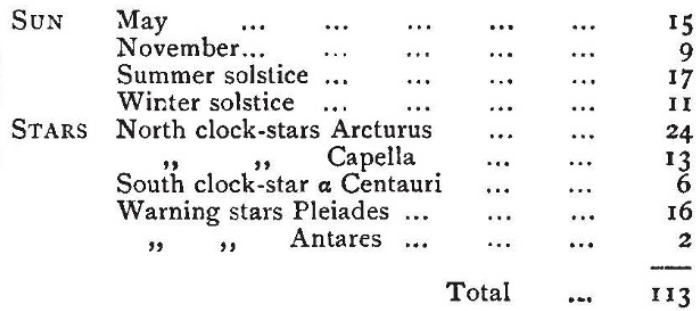

It will be seen how overwhelming the evidence is becoming that blind chance had nothing to do with the setting out of the various alignments, how they all fall into a few definite groups, and how the large mass of evidence now accumulated entirely justifies the conclusions derived from those first placed on record.

With regard to the dates given later on, all NO. 2064, VOL. 8o] 
are approximate only; there is nothing perfect about them. The Welsh Commission and the other commissions will, I hope, make measures, using solar instead of magnetic methods, and determine the height of hills in minutes instead of half degrees, and if they do that these dates will certainly be changed, though they cannot be changed very much.

I have already shown that the May year and the solstitial year had temples sacred to them in Egypt. I may now add that in the Egyptian temples we found one set for the northern stars, the equivalents of Arcturus and Capella, and another set for the southern stars, among them $\alpha$ Centauri. One of the most recent results of this inquiry has been that we have found a number of avenues, not circles, in Brittany and in different parts of Britain, not in Cornwall, the equivalents of the Egyptian temples aligned to the southern stars. The probable alignment corresponds with the southern star a Centauri. There is the Challacombe avenue on Dartmoor, the Borobridge avenue near Harrogate, and others at Avebury and Shap.

Now if we deal with the "clock-stars" in order of date, $\alpha$ Centauri comes first, B.c. $3600-2700$. This is followed a thousand years later by Arcturus, B.c. $2600-1350$, and Capella, B.C. 2250-1250. In all these cases there is a complete series of dates from one end to the other. Now these are the "clockstars."

Coming to the warning stars, it will be noted that the Pleiades were observed rising, and Antares setting, heliacally-that is, about an hour before sunrise. The dates are:-Pleiades, B.c. 2120-1000; Antares, B.c. 1720-1310.

We see that about the same dates are involved as those found in connection with the northern "clock-stars," and this, of course, strengthens the view that we are really dealing with alignments set out for a definite purpose at a definite time. The story, then, is that astronomer-priests familiar with Egyptian methods began work here by building avenues in different parts of Britain about 3600 B.c.

The star employed as a "clock-star," then, was $\alpha$ Centauri, one of the stars used in Egypt. This cult was succeeded by another, in connection with which circles were introduced and northern " clock-stars" were used. This was the chief cult in Cornwall from 2600 B.c. onwards.

If we accept the dates thus astronomically revealed by the stellar alignments, several interesting consequences follow. The British circles were in full work more than a thousand years before the Aryans or Celts came upon the scene, if the time of their arrival favoured by archæologists is anything like correct. Stonehenge began as a May temple-a British Memphis-and ended as a solstitial one like that of Amen-Ra at Thebes. Another conclusion is that, whatever else went on some four thousand years ago in the British circles, there must have been much astronomical observation and a great deal of preparation for it. Some of the outstanding stones must have been illuminated at night, so that we have not only to consider that the priests and deacons must have had a place to live in, but that a sacred fire must have been kept going perpetually, or that there must have been much dry wood available. The question, then, is raised whether dolmens, chambered barrows and the like were places for the living rather than for the dead, and, therefore, whether the burials found in some do not belong to a later time.

The determination of dates, in conjunction with the NO. 2064, VOL. 80] conclusions arrived at concerning the various kinds of monuments, opens up another point of view which possibly in the future may lead to fruitful inquiries.

Why have we in different temple regions such great differences in the relative numbers of avenues, cromlechs, and circles, the extreme case being that only one class is represented?

When the order of the evolution of the different classes of structure is settled, the geographical distribution of them may lead us to further conclusions. The tremendous development of avenues in Brittany and in some parts of Britain where circles are almost entirely absent suggests that a people came here who knew nothing about circles, but did know much about avenues. These in Britain to which I refer were on a scale almost rivalling that of the Brittany avenues. The avenue at Shap was more than a mile long, that at Borobridge was nearly a mile long, and some of the stones were more than 20 feet high. The avenue at Challacombe must, when complete, have been a most stupendous monument. Further, the builders of all these worshipped a southern star; they were not miners, they did not go to Cornwall, and there is a difference of more than rooo years in the dates derived from these avenue-builders and from the circle-builders of Cornwall and South Wales.

It may be worth while to refer briefly to some of the objections still urged against the orientation theory by those who are either unwilling or incompetent to test it by actual observations.

One is that there are so many stars that any align. ment is certain to hit the rising-or setting-place of one of them. The fact that, with all the host of heaven to choose from, only six stars were used, and those among the brightest visible in these latitudes, and, further, that a good reason has been found for using those particular stars, is a strong argument against this objection.

Another objection made is that the theory demands a much greater knowledge of astronomy than the early temple-builders were likely to possess.

Those who put forward this objection entirely forget the conditions under which early man lived and moved and had his being. The conditions now are so different that we must not be astonished at the early peoples apparently behaving like astronomers; they could not behave like any other kind of men. The movements of the sun by day and the movements of the stars by night were the only things they could learn about, and it was imperative that they should learn about them.

People without almanacks and without any idea of the length of a year would find life absolutely impossible, at all events from the agricultural operations point of view, unless they could get, somehow or other, a general means of telling when they should plough and sow and reap. That depends upon the time of the year, and the time of year is written out very large indeed to anybody who will take the trouble to note where the sun rises. Similarly, if these people wanted to know about the flow of time at night, they would be under very great difficulties. In the first place, they had no clocks, so that unless they could get some idea of the time at night by observing the stars they would be entirely out of it so far as the lapse of time during the obscured part of their lives was concerned.

It no doubt is difficult for the average Englishman of the present day, unless he happens to he a sailor, to picture to himself a townless world without artificial light and any useful purpose served by loriking at the sun by day or the stars at night. Calendars, 
almanacks, clocks, and watches have done away with the necessity of using his eyes in this direction, and the modern priest, like the modern layman, though he prates about the heavens declaring the glory of God and the firmament showing $\mathrm{His}$ handiwork, too often does not know that the sun rises to the eastward, and, if he does, he imagines that it rises in the same place all the year round; natura rerum does not interest him.

The ancient priest need not have been a profound astronomer to build the monuments, which were simply calendars. I do not mean to say they were calendars and nothing more, but they were, from an astronomical point of view, simply calendars, enabling people to know and recognise from past experience the different parts of the year by the place of sunrise or sunset, and they were also nightdials, enabling them to differentiate between the early and the late hours of the night.

In my inquiry I have not confined myself to the astronomical side of the question. I have tried to dip into the folklore and tradition already garnered in relation, not only to the sacred stones, but to the sacred wells and sacred trees.

From what I have learned I am convinced that much light will be thrown on both when an attempt shall have been made to picture what the lives of the first British astronomer-priests must necessarily have been.

It is interesting to note that, while the astronomical side of the inquiry suggests a close connection with Egyptian thought, the folklore and traditions, when studied in relation with the monuments, indicate a close connection between the ancient British and the Semitic civilisations.

I do not wish for one moment to suggest that the work in all these various kinds of monuments was limited to practical astronomical purposes. Our traditions render that view impossible. There was worship in its highest forms, perhaps in its lowest forms; there was magic, there were all sorts of things going on in relation to the wants of the people, and it was because there were some people who did know all that was required to meet general and special needs, including their agricultural wants, that they eventually became priests, because they were the men who knew, and that I believe to be the origin of priestly power throughout the world.

This work, if subsequently confirmed by other investigators, has the double advantage of supplying us pretty accurately with the date of erection of the monuments and of indicating the methods of observing the movements of the sun and stars employed in Britain in prehistoric times; and if risings and settings were so abundantly utilised-for utility as well as priestcraft was certainly at the bottom of it-in Britain four thousand years ago, the remarkable testimony to the knowledge and wisdom of the "Druids" given by Cæesar and Pomponius Mela two thousand years nearer their time is now seen to be amply justified.

Multa praeterea de sideribus et eorum motu, de mundi magnitudine, de rerum natura, de deorum immortalium vi ac potestate disputant et juventuti tradunt.-Caes. De Bello Gallico, VI., c. I4.

$\mathrm{Hi}$ terrae mundique magnitudinem et formam, motus coeli ac siderum, ac quod dii velunt scire, profitentur.Fomp. Mela, II., c. 2.

The "Druids" of Cæsar's time were undoubtedly the descendants of the astronomer-priests some of whose daily work has now perhaps at last been revealed.

NO. 2064 , vOL. 801

NORMAN LOCKYER.
RECENT STUDIES ON ANIMAL AND PLANT LIFE. ${ }^{1}$

(1) THE second volume of "Nature-study" consists of three parts. The first of these is composed of chapters by $\mathrm{Mr}$. O. H. Latter on sundry disconnected topics-some insects, centipedes, spiders, a mussel, and a snail. The second, written by Miss Newbigin, treats of fresh-water and marine aquaria. The last describes the haunts of animals and methods of field observation. It is due to Prof. Arthur Thomson. With such able coadjutors, the editor could hardly fail to produce a work of permanent value and of practical suggestiveness. The articles, taken singly, are excellent. The subjects are treated with accuracy and first-hand knowledge; practical difficulties are faced and often solved; lines of thought are suggested from a single fact. The only thing lacking is a better coordination between the topics, and the want of it has led, in this volume. to a regrettable amount of repetition. Mr. Latter describes, for example, the water-beetle and its lifehistory. Miss Newbigin repeats the story in connection with aquaria, and Prof. Thomson refers to it again in dealing with fresh-water faunas. Thus we have five figures of the same beetle and four of its larva (not always consistent). It is called Dyticus at first and Dytiscus afterwards. Repetition also occurs in text and figure as regards the gnat, the pondmussel, certain fish and hydroids. The text in other respects is not edited with care. Thus, with respect to the keeping of the pond-mussel, two of the contributors make contrary statements. These blemishes apart, the work is one that will give much pleasure and information to students of animal life, and stimulate to closer observation. The illustrations are of unequal merit, and many might have been saved or greater variety employed by a keener editor. The anatomical diagram at the commencement represents the structure of the pond-mussel.

(2) Prof. Kellogg, following in the footsteps of Fabre, gives a delightful series of episodes in the life of American insects. These have been told so well by his predecessors that it is difficult to introduce any novelty or charm to the description. But the visitations of insect pests in America give the author an opportunity for some new matter on scalebugs and locusts. We can heartily recommend this little book for reading aloud to children.

(3) Mr. Farrer's rock-garden in Yorkshire is famous, and his advice will be most welcome to all who pursue this attractive form of imitating nature. In the present volume, a continuation of his former work, his experience and zeal are continually manifested, for Mr. Farrer has travelled far to watch and gather his alpines. Most amateur gardeners know too little of the principles on which rock- and boggardens are best planned, or of the natural habitats of the plants employed for stocking them. One of the great charms of this work is the way in which Mr. Farrer takes his readers into the resorts of his favourites, and describes the varying fortunes that have followed his attempts at acclimatisation. There is, for example, a description of the alpines near Arolla. The author's experience should be of great assistance to those who wish to know the best sites and conditions under which this class of plants can

I (1) "The Book of Nature-study." Edited by Prof. J. Bretland Farmer, F.R.S. Vol. ii. Pp. viiitzoz. (London: Caxton Publishlng Co, n.d.) Price $7 s .6 d$.

(2) "Insect Stories." By Vernon L. Ketlogg. Pp. vii +298. (London : G. Pell and Sons; New York: Hrilt and Co.. I908.) Price 5s.

(3) Alpines and Bog Plants." Py Reginald Farrer. Pp. xii +288 London: Edward Arnold, r9o8.) Price 7s. 6d. net.

(4) "Life-histories of Familiar Plants." By John J. Ward. Pp. xx+ 204. (London: Cassell and Co., Itd., rgo8.) Price $6 s$. 